\title{
PENGARUH DIKLAT TERHADAP PENINGKATAN KOMPETENSI KEPALA MADRASAH IBTIDAIYAH
}

\author{
INFLUENCE OF TRAINING ON THE IMPROVEMENT OF \\ COMPETENCE OF PRINCIPALS OF MADRASAH IBTIDAIYAH
}

\author{
Junaidi \\ Widyaiswara Madya Balai Diklat Keagamaan Semarang \\ Jl. Temugiring, Banyumanik Telp (024) 7460290 Semarang \\ Junaidi_soebroto60@yahoo.com
}

\begin{abstract}
This study aims to determine the extent of the increased competence of madrasah principals related to additional tasks of Madrasah Ibtidaiyah principals batch IV and $V$ after attending training organized by the training center in 2015. The experimental design used in this study is one group pretest - posttest design that provides pre-test and post-test after a treatment. The sample was saturated sample in which the sample is all the population of the participants of the additional task debriefing task for madrasah principals batch IV and batch $V$. Normality the test is done to determine the distribution of normal distribution of data or not. This study uses an analytical method with small samples $(\leq 50)$, the test data normality using the Shapiro-Wilk test with the confidence value used of 0.95 and significance value of $\alpha=0.05$. To view whether the data distribution is normal or not is done if the $p$ value is $>0.05$ the data distribution is normal and when the $p$ value is $<0.05$ then the data distribution is not normal. Results of the data analysis determines the effect of the training on the competency of principals, it appears that the average difference of competence of principals in batch $I V$ and batch $V$ before and after the training is 70.2000. The Mann Whitney test results showed that the $p$-value is $0.000<\alpha(0.05)$. It is concluded that the training has effect on the competence of principals.
\end{abstract}

Key Words: Effect, Training Additional Tasks, Competence
Abstrak

Penelitian ini bertujuan untuk mengetahui sejauh mana peningkatan kompetensi kepala madrasah terkait dengan tugas tambahan kepala madrasah Ibtidaiyah angkatan IV dan V setelah mengikuti diklat yang diselenggarakan oleh balai diklat pada tahun 2015. Desain eksperimen yang digunakan dalam penelitian ini berbentuk one group pretest - posttest design yaitu memberikan prestest dan posttest setelah di berikan treatment/perlakuan. Sampel penelitian ini adalah sampel jenuh di mana sampelnya adalah semua populasi yaitu peserta diklat substansi pembekalan tugas pembekalan tugas tambahan kepala madrasah angkatan IV dan V. Uji normalitas dilakukan untuk mengetahui sebaran data berdistribusi normal atau tidak. Penelitian ini menggunakan metode analitik dengan sampel kecil ( $\leq 50)$ maka uji normalitas data menggunakan uji shapiro-wilk dengan ketentuan nilai keyakinan yang dipakai adalah 0,95 dan nilai kemaknaan $\alpha$ $=0,05$. Untuk melihat distribusi data normal atau tidak dengan cara, jika $p$ value $>0,05$ maka distribusi data normal dan bila $p$ value $<0,05$ maka distribusi data tidak normal. Hasil analisis data mengetahui pengaruh diklat terhadap kompetensi kepala madrasah, terlihat bahwa selisih rata-rata kompetensi kepala madrasah angkatan IV dan $V$ sebelum dan sesudah diberikan diklat sebesar 70,2000. Hasil uji Mann whitney menunjukkan bahwa $p$-value sebesar $0,000<\alpha(0,05)$. Disimpulkan bahwa ada pengaruh diklat terhadap kompetensi kepala madrasah.

Kata Kunci: Pengaruh, Diklat Tugas Tambahan, Kompetensi

Naskah diterima 23 Februari 2015. Revisi pertama, 13 Maret 2015. Revisi kedua, 22 Maret 2015 dan revisi terahir 5 April 2015 


\section{PENDAHULUAN}

Tugas kementerian agama selain dalam penyelenggaraan keagamaan juga menyelenggarakan pendidikan agama yang disebut madrasah. Menurut PMA 29 tahun 2014 madrasah adalah satuan pendidikan formal dalam binaan Menteri Agama yang menyelenggarakan pendidikan umum dan kejuruan dengan kekhasan agama Islam yang mencakup Raudhotul Athfal (RA), Madrasah Ibtidaiyah (MI), Madrasah Tsanawiyah (MTs), Madrasah Aliyah (MA), dan Madrasah Aliyah Kejuruan (MAK). Masing-masing tingkatan mempunyai pimpinan yang disebut kepala madrasah. ${ }^{1}$

Keberhasilan madrasah selain ditentukan oleh guru, pegawai, dan peserta didik, sangat ditentukan oleh kepemimpinan kepala madrasah. Menurut Yulk mendefinisikan kepemimpinan merupakan proses untuk mempengaruhi orang lain untuk memahami dan setuju dengan apa yang perlu dilakukan dan bagaimana tugas itu dilakukan secara efektif, serta proses untuk memfasilitasi upaya individu dan kolektif untuk mencapai tujuan bersama². Sedangkan menurut Ralp M.Stogdill dalam Purwanto mengatakan kepemimpinan adalah proses mempengaruhi kegiatankegiatan suatu kelompok yang di organisasi menuju kepada penentuan dan pencapaian tujuan ${ }^{3}$. Sehingga dari pengertian tersebut seorang pemimpin harus mampu mempengaruhi dan menggerak komponenkomponen yang ada di madrasah.

${ }^{1}$ Peraturan Menteri Agama, No 29 tahun 2014 Pasal 1 Tentang Kepala Madrasah

${ }^{2}$ Gary Yulk. 2009. Kepemimpinan dalam Organisasi. Jakarta: PT.Macanan Jaya Cemerlang

${ }^{3}$ Ngalim Purwanto. 2003. Administrasi dan Supervisi Pendidikan. Bandung: Remaja Rosda Karya
Untuk menggerakkan komponen yang ada di madrasah, seorang kepala memerlukan seni dan kemampuan dalam mempengaruhi orang lain untuk berbuat. Gaya kepemimpinan yang ideal adalah menggunakan semua gaya yang ada sebaik mungkin. Artinya gaya kepemimpinan di sesuaikan dengan kondisi yang ada. ${ }^{4}$

Keberhasilan kepemimpinan kepala madrasah terutama dilandasi oleh dalam memimpin. Kunci bagi kelancaran kerja kepala madrasah terletak pada stabilitas dan emosi dan rasa percaya diri. Hal ini merupakan landasan psikologis untuk memperlakukan stafnya secara adil, memberikan keteladanan dalam bersikap, bertingkah laku dan melaksanakan tugas. Kepala madrasah juga dituntut mempunyai kompetensi yang baik dalam memimpin madrasah. Menurut W. Robert Houston dalam Roestiyah NK. ${ }^{5}$ kompetensi yaitu suatu tugas yang memadai, atau pemilikan pengetahuan, keterampilan dan kemampuan yang dituntut oleh jabatan seseorang, sehingga untuk memimpin madrasah harus mempunya kompetensi yang di persyaratkan.

Madrasah adalah lembaga yang bersifat kompleks dan unik karena madrasah sebagai organisasi di dalam terdapat terdapat berbagai dimensi yang satu sama lain saling berkaitan dan menentukan, sedangkan unik karena madrasah memiliki ciri-ciri tertentu yang tidak dimiliki oleh organisasi lain.

Seorang kepala madrasah harus mempunyai visi yang jelas, karena visi merupakan atribut pemimpin termasuk

${ }^{4}$ Timpe A. Dale. 1999. Seri Manajemen Sumber Daya Manusia: Kinerja. Jakarta: Media Komputindo

${ }^{5}$ Roestiyah NK. 1989. Masalah-masalah Ilmu Keguruan. Jakarta: PT.Bina Aksara 
kepemimpinan kepala madrasah. Kepala madrasah yang visinya dangkal dan tidak jelas akan membawa kemunduran madrasah dan akan menghasilkan madrasah yang kurang berkualitas. Menurut Departemen Agama karakteristik kepala madrasah yang memiliki visi yang utuh dapat diindentifikasi yaitu: (1) Berniat ibadah dalam melaksanakan tugasnya; (2) Beragama dan taat akan ajaran agama yang dianutnya; (3) Berniat baik sebagai kepala madrasah; (4) berlaku adil dalam memecahkan masalah; (5) berkeyakinan bahwa bekerja di lingkungan madrasah merupakan dan panggilan jiwa; (5) Bersikap tawadhu (rendah hati); (6) berhasrat untuk memajukan madrasah; (6) tidak terlalu berambisi terhadap imbalan materi dari hasil pekerjaannya; dan (7) bertanggung jawab terhadap segala ucapan dan perbuatannya. ${ }^{6}$

Karakteristik dari visi tersebut diharapkan baik oleh pemerintah, masyarakat dan orang tua sesuai tuntutan zaman sehingga madrasah diharapkan menjadi pusat keunggulan atau center of excellence. Untuk mewujudkan hal tersebut maka diperlukan kepala madrasah yang mempunyai visi yang jelas, komplit tentang madrasah dan berorientasi ke masa depan. Dengan demikian jika seorang kepala mampu menyusun dan melaksanakan visi dapat dikatakan kompeten dan profesional.

Kepala madrasah dikatakan kompeten dan profesional apabila mereka mampu melaksanakan peranannya sebagai seseorang yang diberi tanggung jawab dalam memimpin madrasah dan mampu me-

\footnotetext{
${ }^{6}$ Departemen Agama RI, KMA No. 1 tahun 2001 Tentang Kedudukan, Tugas, Fungsi, Kewenangan, Susunan Oganisasi dan Tata Kerja Departemen Agama. Jakarta: Badan Litbang dan Diklat Departemen Agama.
}

mahami keberadaan madrasah sebagai organisasi yang kompleks dan unik

Tanggung jawab kepala madrasah dalam melakukan tugas utamanya adalah sebagai guru yang melakukan pembelajaran, sedangkan tugas tambahan sebagai pemimpin yang selanjutnya disebut tugas yang berkaitan dengan manajerial, perencanaan strategis, supervisi akademik, kepemimpinan pembelajaran, dan manajemen keuangan. Untuk mengukur tugastugas tersebut berhasil atau tidak maka dapat dilakukan penilaian kompetensi kepala madrasah oleh pengawas atau pejabat yang berwenang.

Berdasarkan data yang ada di Kementerian Agama, sebagian besar madrasah yang ada di provinsi Jawa Tengah dan D.I Yogyakarta belum menyusun komponenkomponen yang terkait tugas tambahan, seperti rencana kerja madrasah (RKM) yang disusun belum berdasarkan hasil evaluasi diri Madrasah (EDM) dengan demikian RKM belum menggambarkan kondisi yang sebenarnya madrasah tersebut. Hal ini akan berdampak pada penilaian kompetensi kinerja kepala madrasah dari unsur tugas tambahan.

Berdasarkan uraian di atas, penulis tertarik untuk melakukan penelitian tentang pengaruh pelaksanaan diklat teknis substantif pembekalan tugas tambahan kepala madrasah yang di selenggarakan Balai Diklat Keagamaan Semarang dengan judul Pengaruh Diklat Terhadap Peningkatan Kompetensi Kepala Madrasah Ibtidaiyah Angkatan IV dan V di Provinsi Jawa Tengah dan D.I Yogyakarta Tahun 2015.

Berdasarkan latar belakang masalah yang telah diuraikan, maka permasalahan 
dirumuskan adalah Pengaruh Diklat Terhadap Peningkatan Kompetensi Kepala Madrasah Ibtidaiyah Angkatan IV dan V di Provinsi Jawa Tengah dan D.I Yogyakarta Tahun 2015.

\section{KERANGKA TEORITIK}

\section{Pendidikan dan Pelatihan}

Pendidikan dan pelatihan pada hakikatnya merupakan salah satu bentuk kegiatan dari program pengembangan sumber daya manusia (personal development). Pengembangan sumber daya manusia sebagai salah satu mata rantai (link) dari siklus pengelolaan personil dapat diartikan: merupakan proses perbaikan staf melalui berbagai macam pendekatan yang menekankan realisasi diri (kesadaran), pertumbuhan pribadi dan pengembangan diri. Pengembangan mencakup kegiatankegiatan yang bertujuan untuk perbaikan dan pertumbuhan kemampuan (abilities), sikap (attitude), keterampilan (skill), dan pengetahuan anggota organisasi.

Menurut Notoatmodjo diklat selain untuk meningkatkan kemampuan staf yang menduduki suatu jabatan tertentu juga dilakukan untuk meningkatkan produktivitas kerja. ${ }^{7}$ Dengan peningkatan produktivitas kerja para pegawai/karyawan organisasi yang bersangkutan akan memperoleh keuntungan. Pendapat Notoatmodjo tersebut menekankan betapa pentingnya diklat bagi pegawai/karyawan dalam proses pencapaian tujuan atau keberhasilan organisasi. Kemampuan dan keterampilan pegawai dipandang sebagai modal yang sangat besar dalam peningkatan

\footnotetext{
7 Soekidjo Notoatmodjo. 1998. Pengembangan Sumberdaya Manusia. Jakarta: Penerbit Rineka Cipta
}

produktivitas kerja, Oleh karenanya diklat merupakan suatu hal yang seharusnya dilaksanakan secara terus-menerus dan berkesinambungan.

Hal senada dikemukakan The Trainer's Library dalam Soebagio Atmodiwirio adalah seluruh kegiatan yang didesain untuk membantu meningkatkan pegawai memperoleh pengetahuan, keterampilan dan meningkatkan sikap, perilaku yang dibutuhkan untuk melaksanakan pekerjaan dengan baik yang sekarang menjadi tanggung jawabnya sehingga tujuan organisasi dapat tercapai. ${ }^{8}$

Sedangkan menurut Peraturan Pemerintah Nomor 101 Tahun 2000 tentang Pendidikan dan Pelatihan Jabatan Pegawai Negeri Sipil, disebutkan "Pendidikan dan pelatihan Jabatan Pegawai Negeri Sipil yang disebut Diklat adalah proses penyelenggaraan belajar mengajar dalam rangka meningkatkan kemampuan Pegawai Negeri Sipil". ${ }^{2}$ Pendidikan dan pelatihan kepegawaian juga merupakan bagian dari sebuah sistem pembinaan karier Pegawai Negeri Sipil yang bermakna pada pengembangan kepegawaian.

Dari beberapa pendapat di atas disimpulkan bahwa diklat adalah "serangkaian kegiatan yang didesain untuk meningkatkan pengetahuan, keterampilan dan meningkatkan sikap, perilaku pegawai negeri sipil dalam menjalankan tugas sehingga tujuan organisasi dapat tercapai"

8 Soebagio Atmodiwirio. Manajemen Pelatihan. 2002. Jakarta: PT Ardadizya Jaya

${ }^{9}$ Peraturan Pemerintah Nomor 101 Tahun 2000 Tentang Pendidikan dan Pelatihan Jabatan Pegawai Negeri Sipil 


\section{Kepala Madrasah}

Secara garis besar, ruang lingkup tugas kepala madrasah dapat diklasifikasikan ke dalam dua aspek pokok, yaitu pekerjaan di bidang administrasi madrasah dan pekerjaan yang berkenaan dengan pembinaan profesional kependidikan. Untuk melaksanakan tugas tersebut dengan sebaik-baiknya, ada tiga jenis keterampilan pokok yang harus dimiliki oleh kepala madrasah sebagai pemimpin pendidikan yaitu keterampilan teknis (technical skill), keterampilan berkomunikasi (human relations skill) dan keterampilan konseptual (conceptual skill).

Menurut PMA No 29 tahun 2014, kepala madrasah adalah guru yang di beri tugas tambahan untuk memimpin penyelenggaraan pendidikan pada madrasah. ${ }^{10}$ Sedangkan menurut Permendiknas No 28 tahun 2010 Kepala sekolah/madrasah adalah guru yang diberi tugas tambahan untuk memimpin taman kanak-kanak/raudhotul athfal (TK/RA), taman kanak-kanak luar biasa (TKLB), sekolah dasar/madrasah ibtidaiyah (SD/MI), sekolah dasar luar biasa (SDLB), sekolah menengah pertama/ madrasah tsanawiyah (SMP/MTs), sekolah menengah pertama luar biasa (SMPLB), sekolah menengah atas/madrasah aliyah (SMA/MA), sekolah menengah kejuruan/ madrasah aliyah kejuruan (SMK/MAK), atau sekolah menengah atas luar biasa (SMALB) yang bukan sekolah bertaraf internasional (SBI) atau yang tidak dikembangkan menjadi sekolah bertaraf internasional (SBI), Sehingga dapat di simpulkan bahwa kepala madrasah adalah guru yang di beri tugas tambahan untuk memimpin dan

\footnotetext{
${ }^{10}$ Ibid
}

bertanggung jawab dalam penyelenggaraan pendidikan dari tingkat RA sampai dengan MA/MAK. ${ }^{11}$

Kepala madrasah sebagai pimpinan diharapkan mampu menjadi penyumbang keberhasilan dalam penguatan tata kelola, akuntabilitas dan pencitraan publik pendidikan Indonesia. Keberhasilan kepala madrasah dalam meningkatkan kualitas pendidikan di madrasah sangat ditentukan oleh penguasaan kompetensi dalam menjalankan tugas, peran, dan fungsi sebagai kepala madrasah.

\section{Kompetensi}

Menurut Cece Wijaya dan Tabrani Rusyan menjelaskan kompetensi adalah kemampuan yang merupakan gambaran hakikat kualitatif dari perilaku guru atau tenaga kependidikan yang tampak sangat berarti ${ }^{12}$. Hal senada di kemukakan Usman kompetensi adalah suatu hal yang menggambarkan kemampuan seseorang, baik yang bersifat kualitatif maupun kuantitatif. ${ }^{13}$ kompetensi dapat digunakan dalam dua konteks, konteks pertama sebagai indikator yang menunjukkan kepada perbuatan yang diamati, konteks kedua sebagai konsep yang mencakup aspekaspek kognitif, afektif, dan perbuatan serta tahap-tahap pelaksanaannya secara utuh. Jadi, menurut Usman kompetensi guru diberikan pengertian sebagai kemampuan

${ }^{11}$ Peraturan Menteri Pendidikan dan Kebudayaan No 28 Tahun 2010 Tentang Penugasan Guru Sebagai Kepala Sekolah/Madrasah

12 Cece Wijaya dan Tabrani Rusyan. 1994. Kemampuan Dasar Guru Dalam Proses Belajar Mengajar. Bandung: PT Remaja Rosdakarya,

${ }^{13}$ Moh.Uzer Usman. 1995. Menjadi Guru Profesional. Ed.2, Cet-22, Bandung: PT Remaja Rosdakarya 
dan kewenangan guru dalam melaksanakan profesi keguruannya. Dari uraian di atas disimpulkan kompetensi adalah kemampuan seorang dalam mengelola bidang tugasnya yang terkait dengan pengetahuan, keterampilan dan sikap sehingga apa yang menjadi pekerjaan dapat di selesaikan sesuai dengan tujuannya. Salah satu cara untuk mengetahui kompetensi seorang kepala madrasah dengan melakukan penilaian. menurut Berk dalam Djemari Merdapi penilaian kinerja adalah proses pengumpulan data dengan cara pengamatan yang sistematik untuk membuat keputusan tentang individu. ${ }^{14}$

\section{Metode Penelitian}

Metode penelitian ini yang digunakan dalam penelitian ini berbentuk one group pretest-posttest design yaitu memberikan pretest dan posttest setelah diberikan treatment/perlakuan. Menurut Sugiyono metode penelitian eksperimen digambarkan sebagai berikut:

$0_{1}$ : nilai pretest (sebelum diberi diklat)

$\mathrm{X}$ : Treatment yang diberikan (variabel independent)

$0_{2}$ : nilai posttest (setelah diberi diklat) $)^{15}$

Tabel 1: Rancangan Desain Penelitian

\begin{tabular}{|l|l|l|l|l|}
\hline \multicolumn{1}{|c|}{ Peserta } & Pengambilan & Pretest & Perlakuan & Postest \\
\hline $\begin{array}{l}\text { Peserta Diklat substansi } \\
\text { pembekalan tugas } \\
\text { pembekalan tugas } \\
\text { tambahan kepala } \\
\text { madrasah }\end{array}$ & A & 0 & $X$ & 0 \\
\hline
\end{tabular}

${ }^{14}$ Djemari Mardapi.2012. Pengukuran Penilaian \& Evaluasi Pendidikan. Yogyakarta: Nuha Medika

${ }^{15}$ Sugiyono. 2013. Metode Penelitian Manajemen. Bandung: Alfabeta
Keterangan:

A: pengambilan sampel ditentukan

$\mathrm{O}$ : pretes dan postes

$\mathrm{X}$ : perlakuan diklat substansi pembekalan tugas pembekalan tugas tambahan kepala madrasah

\section{HASIL DAN PEMBAHASAN}

\section{Uji Normalitas Data}

Uji normalitas dilakukan untuk mengetahui apakah sebaran data berdistribusi normal atau tidak. Penelitian ini menggunakan metode analitik dengan sampel kecil $(\leq 50)$ maka uji normalitas data menggunakan uji shapiro-wilk dengan ketentuan nilai keyakinan yang dipakai adalah 0,95 dan nilai kemaknaan $\alpha=0,05$. Untuk melihat distribusi data normal atau tidak dengan cara, jika $p$ value $>0,05$ maka distribusi data normal dan bila $p$ value $<0,05$ maka distribusi data tidak normal.

Hasil uji normalitas dalam penelitian ini disajikan pada tabel sebagai berikut:

Tabel 2. Hasil Uji Normalitas Data

\begin{tabular}{|l|l|r|r|r|}
\hline \multirow{2}{*}{ Kelompok } & \multirow{2}{*}{ Perlakuan } & \multicolumn{3}{|c|}{ Shapiro Wilk } \\
\cline { 3 - 5 } & & \multicolumn{1}{|c|}{ Statistik } & \multicolumn{1}{c|}{ df } & \multicolumn{1}{c|}{ Sign } \\
\hline $\begin{array}{l}\text { Kepala } \\
\text { Angkatan 1V }\end{array}$ & Sebelum & 0,933 & 30 & 0,060 \\
\cline { 2 - 5 } & Sesudah & 0,866 & 30 & 0,001 \\
\hline \multirow{2}{*}{$\begin{array}{l}\text { Kepala } \\
\text { Angkatan V }\end{array}$} & Sebelum & 0,977 & 30 & 0,752 \\
\cline { 2 - 5 } & Sesudah & 0,860 & 30 & 0,001 \\
\hline
\end{tabular}

Berdasarkan tabel 2 terlihat hasil uji shapiro wilk menunjukkan masing-masing kelompok sebelum dan sesudah perlakuan mempunyai nilai $p$ value $>\alpha(0,05)$, sehingga dapat disimpulkan bahwa data hasil penelitian mempunyai distribusi normal 
sehingga layak untuk dianalisis lebih lanjut yaitu dengan menggunakan uji parametrik.

\section{Uji Homogenitas atau Kesetaraan Data}

Pengujian homogenitas ini bertujuan untuk melihat homogen (kesamaan varians). Guna mengetahui kesetaraan kedua kelompok yang terpilih digunakan instrumen tes kesetaraan kelompok. Selanjutnya untuk menguji ada tidaknya perbedaan rata-rata skor hasil tes kesetaraan kelompok digunakan uji mann whitney karena data berdistribusi normal, di mana kriteria pengujian yang digunakan jika t-hitung > t-tabel pada derajat kebebasan n-2 dan taraf signifikansi 5\%, maka kelompok dinyatakan setara (tidak berbeda secara signifikan).

Hasil uji kesetaraan (homogenitas data) dalam penelitian ini disajikan pada tabel 3 sebagai berikut:

Tabel 3. Hasil Uji Kesetaraan Kelompok Kepala Angkatan V dan Kepala Angkatan IV Sebelum diklat

\begin{tabular}{|c|l|c|c|c|c|r|}
\hline \multicolumn{2}{|c|}{ Kelompok } & $\mathrm{n}$ & Mean & SD & $\mathrm{Z}_{\text {hitung }}$ & $p$-value \\
\hline Pretest & $\begin{array}{l}\text { Kepala } \\
\text { Angkatan IV }\end{array}$ & 30 & 28,58 & 7,39749 & $-0,858$ & 0,391 \\
\cline { 2 - 7 } & $\begin{array}{l}\text { Kepala } \\
\text { Angkatan V }\end{array}$ & 30 & 32,42 & & & \\
\hline
\end{tabular}

Berdasarkan hasil uji kesetaraan menunjukkan bahwa tidak ada beda kompetensi sebelum diberikan pemberian diklat dengan $p$ value sebesar $0,391(\alpha=0,05)$, artinya kompetensi sebelum diberikan diklat adalah setara yaitu data sebelum perlakuan antara kelompok Kepala Angkatan IV dan Kepala Angkatan V itu sama sehingga dapat dibandingkan.

\section{Perbedaan Kompetensi Peserta diklat Sebelum dan Sesudah Diberikan Diklat pada Kepala angkatan IV}

Guna mengetahui perbedaan kompetensi peserta diklat sebelum dan sesudah diberikan padakepalaangkatanIV digunakan uji wilcoxon rank test. Hasil uji wilcoxon rank test dengan program pengolahan data SPSS Versi 17.0 disajikan sebagai berikut:

Tabel 4. Perbedaan kompetensi Peserta Sebelum dan Sesudah Diberikan Diklat pada Kepala angkatan IV

\begin{tabular}{|l|r|r|r|l|}
\hline & \multicolumn{1}{|c|}{$N$} & Mean & $Z_{\text {hitung }}$ & p-value \\
\hline $\begin{array}{l}\text { Kepala } \\
\text { angkatan IV }\end{array}$ & 30 & $' 15,5$ & $-4,783$ & 0,000 \\
\hline
\end{tabular}

Berdasarkan Tabel 4 tersebut dapat diketahui bahwa dari 30 kepala angkatan IV yang diberikan diklat pada kepala angkatan IV skor perbedaan rata-rata kompetensi sebelum diklat sebesar 15,5. Berdasarkan uji wilcoxon rank test menunjukkan pula bahwa $p$ value $(0,000)<\alpha(0,05)$, sehingga dapat disimpulkan bahwa ada perbedaan kompetensi peserta diklat sebelum dan sesudah diberikan diklat pada kepala angkatan IV.

\section{Perbedaan Kompetensi Peserta diklat Sebelum dan Sesudah Diklat pada kepala Madrasah angkatan $V$}

Guna mengetahui perbedaan kompetensi peserta diklat sebelum dan sesudah penelitian pada kepala angkatan $\mathrm{V}$ digunakan uji wilcoxon rank test. Hasil uji wilcoxon rank test dengan program pengolahan data SPSS Versi 17.0 disajikan sebagai berikut: 
Tabel 5. Perbedaan Kompetensi Peserta diklat Sebelum dan Sesudah pada Kepala angkatan V

\begin{tabular}{|l|r|r|r|r|}
\hline & \multicolumn{1}{|c|}{$n$} & Mean & $Z_{\text {hitung }}$ & \multicolumn{1}{c|}{-value } \\
\hline Kepala angkatan V & 30 & $` 15,5$ & $-4,784$ & 0,000 \\
\hline
\end{tabular}

Berdasarkan tabel 5 tersebut dapat diketahui bahwa dari 30 kepala angkatan $\mathrm{V}$ yang diberikan diklat pada kepala angkatan $\mathrm{V}$ skor perbedaan rata-rata Kompetensi sebelum diklat sebesar 15,5. Berdasarkan uji wilcoxon rank test menunjukkan pula bahwa $p$ value $(0,000)<\alpha(0,05)$, sehingga dapat disimpulkan bahwa ada perbedaan p kompetensi peserta diklat sebelum dan sesudah diberikan diklat pada kepala angkatan V.

\section{Pengaruh Diklat Terhadap Kompetesi Kepala Madrasah}

Uji mann whitney digunakan untuk mengetahui pengaruh diklat terhadap kompetensi kepala madrasah, di mana dalam pengujian ini akan dibandingkan data yang berasal dari dua kelompok data yang tidak berpasangan.

Tabel 6. Analisis pengaruh diklat terhadap kompetensi Kepala Madrasah

\begin{tabular}{|c|r|r|r|}
\hline \multicolumn{1}{|c|}{ Variabel } & Mean difference & Z hitung & p-value \\
\hline $\begin{array}{l}\text { Kompetensi kepala } \\
\text { madrasah }\end{array}$ & 70,2000 & $-5,751$ & 0,000 \\
\hline
\end{tabular}

Berdasarkan tabel 6 terlihat bahwa selisih rata-rata kompetensi kepala madrasah angkatan IV sebelum dan sesudah diberikan diklat sebesar 70,2000. Hasil uji Mann whitney menunjukkan bahwa $p$-value sebesar $0,000<\alpha(0,05)$. Hal tersebut menunjukkan ada pengaruh diklat terhadap kompetensi kepala madrasah.

\section{Uji Hipotesis}

Pengujian hipotesis ini bertujuan untuk menguji hipotesis statistik. Guna mengetahui apakah ada perbedaan kompetensi kepala madrasah sebelum dan sesudah diklat digunakan uji dependent $t$ test untuk data yang berdistribusi normal. Uji mann whitney termasuk dalam uji statistik parametrik yaitu uji yang menggunakan asumsi-asumsi data berdistribusi normal dengan varian homogen dan diambil dari sampel yang acak.

Berdasarkan hasil ini diketahui apakah hipotesa yang diajukan diterima atau ditolak dengan ketentuan nilai keyakinan yang dipakai adalah 0,95 dan nilai kemaknaan $\alpha=$ 0,05. Jika $p$ value $<\alpha$, maka Ho ditolak, artinya ada perbedaan kompetensi kepala madrasah sebelum dan sesudah diberikan diklat pada kelompok Kepala Angkatan IV.

Guna mengetahui apakah ada pengaruh diklat terhadap kompetensi kepala sekolah digunakan uji mann whitney karena membandingkan data yang berasal dari dua kelompok data yang tidak berpasangan. Uji mann whitney termasuk dalam uji statistik parametrik yaitu uji yang menggunakan asumsi-asumsi data berdistribusi normal dengan varian homogen.

Berdasarkan hasil ini diketahui apakah hipotesa yang diajukan diterima atau ditolak dengan ketentuan nilai keyakinan yang dipakai adalah 0,95 dan nilai kemaknaan $\alpha=$ 0,05. Jika $p$ value $<\alpha$, maka Ho ditolak, artinya ada pengaruh diklat terhadap kompetensi kepala madrasah di Provinsi Jawa Tengah dan D.I Yogyakarta. 


\section{SIMPULAN}

Berdasarkan uraian dan pembahasan hasil observasi di Balai Diklat Keagamaan Semarang dapat ditarik simpulan sebagai berikut: pertama, hasil uji shapiro wilk menunjukkan masing-masing kelompok sebelum dan sesudah perlakuan mempunyai nilai $p$ value $>\alpha(0,05)$, sehingga dapat disimpulkan bahwa data hasil penelitian mempunyai distribusi normal sehingga layak untuk dianalisis lebih lanjut yaitu dengan menggunakan uji parametrik.

Kedua, hasil uji kesetaraan menunjukkan bahwa tidak ada beda kompetensi sebelum diberikan pemberian diklat dengan $p$ value sebesar 0,391 $(\alpha=0,05)$, artinya kompetensi sebelum diberikan diklat adalah setara yaitu data sebelum perlakuan antara kelompok Kepala Angkatan IV dan Kepala Angkatan V itu sama sehingga dapat dibandingkan.

Ketiga, Hasil Uji mann whitney digunakan untuk mengetahui pengaruh diklat terhadap kompetensi kepala madrasah, terlihat bahwa selisih rata-rata kompetensi kepala madrasah angkatan IV dan V sebelum dan sesudah diberikan diklat sebesar 70,2000. Hasil uji Mann whitney menunjukkan bahwa $p$-value sebesar $0,000<\alpha(0,05)$. Hal tersebut menunjukkan ada pengaruh diklat terhadap kompetensi kepala madrasah.

\section{SUMBER BACAAN}

Atmodiwirio, Soebagio (2002): Manajemen Pelatihan. Jakarta, PT Ardadizya Jaya.

Departemen Agama RI, (2001):KMA No.1 tahun 2001 Tentang Kedudukan, Tugas, Fungsi, Kewenangan, Susunan Oganisasi dan Tata Kerja Departemen Agama. Jakarta: Badan Litbang dan Diklat Departemen Agama.

Kementerian Agama RI (2014) Peraturan Menteri Agama, No 29 tahun 2014 Pasal 1 Tentang Kepala Madrasah

Mardapi,Djemari (2012): PengukuranPenilaian \& Evaluasi Pendidikan. Yogyakarta, Nuha Medika

Purwanto, Ngalim (2003): Administrasi dan Supervisi Pendidikan. Bandung Remaja Rosda Karya

NK, Roestiyah (1989): Masalah-masalah Ilmu Keguruan. Jakarta, PT. Bina Aksara

Notoatmodjo, Soekidjo (2009): Pengembangan Sumber Daya Manusia. Jakarta, Penerbit Rineka Cipta

Peraturan Pemerintah Nomor 101 Tahun 2000 Tentang Pendidikan dan Pelatihan Jabatan Pegawai Negeri Sipil

Peraturan Menteri Pendidikan dan Kebudayaan Nomor 28 tahun 2010 tentang Penugasan Guru Sebagai Kepala Sekolah/Madrasah

Sugiyono (2013): MetodePenelitian Manajemen. Bandung, Alfabeta

Timpe A. Dale (1999): Seri Manajemen Sumber Daya Manusia: Kinerja. Jakarta, Media Komputindo

Usman, Moh. Uzer (1995): Menjadi Guru Profesional, Ed.2, Cet-22. Bandung, PT Remaja Rosdakarya 
Wijaya, Cece dan Rusyan, Tabrani (1994): Kemampuan Dasar Guru dalam Proses Belajar Mengajar. Bandung, PT Remaja Rosdakarya

Yulk, Gary (2009): Kepemimpinan dalam Organisasi. Jakarta, PT. Macanan Jaya Cemerlang 